\title{
NEWMAN'S ERROR ANALYSIS TERHADAP KESALAHAN MAHASISWA PADA MATA KULIAH LOGIKA DAN HIMPUNAN
}

\author{
Yulyanti Harisman ${ }^{1}$, Asep Amam², Marwia Tamrin Bakar ${ }^{2}$ \\ 1 Universitas Negeri Padang, Jl. Prof. Dr. Hamka, Padang, Indonesia \\ 2 Universitas Galuh, Jl. R. E. Martadinata No.150, Ciamis, Indonesia \\ 3 Universitas Khairun, Jl Bandara Sultan Babullah, Ternate, Indonesia \\ Email: yulyanti_h@fmipa.unp.ac.id
}

\begin{abstract}
This research is based on the low grades of students in logic and set courses. Therefore, the purpose of this study is to analyze student errors in Logic and Association lectures using NEA (Newman's Error Analysis). The type of research selected is case study research. The error types of student answers are grouped or classified by NEA. Two questions of mathematical proof are designed to look at the error. The question has been validated by a colleague. The subjects in this study were 69 students who took logic and association courses. The results showed students were more likely to be able to understand the problem but were unable to transform and encode the problem.
\end{abstract}

Keywords: Error, logic and set, newman's error analysis,

\section{ABSTRAK}

Penelitian ini dilatarbelakangi oleh rendahnya nilai mahasiswa pada mata kuliah logika dan himpunan. Oleh sebab itu tujuan dari penelitian ini adalah untuk menganalisis kesalahan mahasiswa pada perkuliahan Logika dan Himpunan dengan menggunakan NEA (Newman's Error Analysis). Jenis Penelitian yang dipilih adalah penelitian studi kasus. Jenis kesalahan dari jawaban mahasiswa dikelompokkan atau diklasifikasikan berdasarkan NEA. Dua soal pembuktian matematis dirancang untuk melihat kesalahan tersebut. Soal telah divalidasi oleh teman sejawat. Subjek dalam penelitian ini adalah 69 orang mahasiswa yang mengambil mata kuliah Logika dan Himpunan. Hasil penelitian menunjukkan mahasiswa cenderung mampu memahami masalah namun tidak dapat mentransformasi dan melakukan pengkodean pada masalah.

Kata kunci: Kesalahan, logika dan himpunan, newman's error analysis,

Dikirim: 21 Juli 2020; Diterima: 27 Agustus 2020; Dipublikasikan: 30 September 2020

Cara sitasi: Harisman, Y., Amam, A., \& Bakar, M. T. (2020). Newman's error analysis terhadap kesalahan mahasiswa pada mata kuliah logika dan himpunan. Teorema: Teori dan Riset Matematika, 5(2), 223-229. 


\section{PENDAHULUAN}

Mata kuliah logika dan himpunan merupakan mata kuliah wajib yang harus diambil mahasiswa pada kurikulum Pendidikan Matematika Universitas Negeri Padang. Mata kuliah ini merupakan mata kuliah yang sangat penting yang harus dipahami oleh mahasiswa tahun pertama, karena termasuk salah satu fondasi untuk memahami mata kuliah berikutnya. Kompetensi pada mata kuliah logika dan himpunan adalah: himpunan dan operasinya, himpunan bilangan dan perkalian cartesius, jenis dan invers fungsi, relasi, aljabar himpunan, dualitas dan himpunan berindeks, himpunan terbilang, logika dan matematika, proposisi, argumen, tautologi, bukti kevalidan fungsi proposisi, dan bukti kevalidan fungsi berkuantor. Berdasarkan kompetensi yang diharapkan pada capaian mata kuliah maka mata kuliah ini bertujuan untuk melatih logika mahasiswa yang dapat diterapkan mahasiswa dalam pemecahan masalah dalam kehidupan sehari-hari.

Permasalahan yang sering terjadi pada setiap angkatan adalah hasil capaian yang diperoleh rendah pada Ujian Tengah Semester dengan materi logika. Hasil belajar mahasiswa pada Ujian Tengah Semester untuk dua angkatan dari dua kelas yang diampu disajikan pada Tabel 1.

Tabel 1. Hasil belajar mahasiswa pada Ujian Tengah Semester

\begin{tabular}{cccc}
\hline Tahun Akademik & $\begin{array}{c}\text { Jumlah mahasiswa yang } \\
\text { memiliki rentang nilai } \\
0-65\end{array}$ & $\begin{array}{c}\text { Jumlah mahasiswa yang } \\
\text { memiliki rentang nilai } \\
66-100\end{array}$ & Jumlah mahasiswa \\
\hline Genap 2019/2020 & 50 orang & 19 orang & 69 orang \\
Genap 2020/2021 & 39 orang & 30 orang & 69 orang \\
\hline
\end{tabular}

Berdasarkan permasalahan tersebut, perlu dilakukan analisis terhadap kesalahan mahasiswa pada materi logika. Indikator analisis kesalahan yang digunakan pada tulisan ini adalah Newman's Error Analysis (NEA).

NEA adalah singkatan dari Newman's Error Analysis (Analisis Kesalahan Newman). Newman (1983) menyatakan bahwa ketika seorang anak menyelesaikan masalah matematika yang tertulis mereka harus bekerja melalui 4 langkah dasar yaitu: membaca (reading), pemahaman (comprehension), transformasi (transformation), pengkodean (encoding). Biasanya siswa ataupun mahasiswa akan melakukan kesalahan pada tahapan-tahapan tersebut.

Beberapa penelitian yang dilakukan ahli untuk menganalisis kesalahan siswa dengan menggunakan NEA adalah: Sumule et al. (2018) meneliti kesalahan siswa SMP (Sekolah Menengah Pertama) dalam mengerjakan tes PISA. Penelitian tersebut bertujuan untuk mengetahui jenis dan penyebab kesalahan, serta upaya yang dilakukan untuk mengatasi kesalahan yang dilakukan oleh siswa SMP dalam menyelesaikan soal PISA pada konten ruang dan bentuk. Pada penelitiannya, dua siswa SMP dipilih untuk mengerjakan soal-soal PISA, dan diperoleh hasil bahwa kesalahan yang banyak dilakukan adalah kesalahan pemahaman dan transformasi. Untuk mengatasi kesalahan ini, siswa diberi scaffolding. Scaffolding yang diberikan kepada siswa untuk mengatasi kesalahpahaman adalah meninjau restrukturisasi, sedangkan untuk mengatasi kesalahan transformasi, scaffolding yang diberikan adalah mengkaji, merestrukturisasi, menjelaskan dan mengembangkan alat representasional. Triliana \& Asih (2019) melakukan penelitian terhadap lima siswa sekolah menengah pertama dari delapan kelas yang tersedia. Siswa diberikan masalah kemudian jawaban siswa dianalisis dengan NEA. Analisis kesalahan Newman ada lima tahap dari (1) membaca; (2) pemahaman; (3) transformasi; (4) keterampilan proses; dan (5) pengkodean. Langkah yang dilakukan adalah mengembangkan tiga tugas, memvalidasi tugas, meminta siswa untuk menyelesaikan tugas, dan menganalisis jawaban siswa. Hasil tersebut menunjukkan bahwa kesalahan siswa berdasarkan analisis kesalahan Newman sering terjadi pada tahap keterampilan membaca, pemahaman dan proses. Son et al. (2019) melakukan penelitian di sekolah menengah pertama sebanyak 30 orang siswa. Penelitian tersebut bertujuan untuk mengungkap kesalahan penyelesaian aljabar siswa berdasarkan indikator Polya dan indikator hirarki Newman. Pengumpulan data menggunakan tes dan wawancara. Hasil tes kemampuan pemecahan masalah siswa dikelompokkan menjadi tiga bagian, yaitu 5 siswa dalam kategori rendah, 20 siswa dalam kategori sedang, dan 5 siswa dalam kategori tinggi. Hasil dari analisis berdasarkan indikator Polya menunjukkan bahwa sekelompok 
siswa rendah melakukan kesalahan semua indikator. Siswa sedang membuat kesalahan dalam melaksanakan rencana dan melihat kembali. Bagi mereka yang berada dalam kategori tinggi, mereka membuat kesalahan dalam indikator melihat kembali. Sedangkan hasil analisis didasarkan pada indikator hirarkis Newman bahwa sekelompok siswa rendah membuat kesalahan mulai dari pemahaman hingga pengodean. Siswa kelompok sedang membuat kesalahan dalam keterampilan proses dan proses pengkodean. Bagi mereka yang termasuk dalam kategori tinggi, mereka cenderung membuat kesalahan pada indikator pengkodean.

Penelitian tersebut merupakan penelitian yang dilakukan pada tingkat sekolah menengah atas dan pertama. Masih jarang analisis kesalahan yang dilakukan di perguruan tinggi. Kristianto et al. (2019) beranggapan bahwa matematika di perguruan tinggi menuntut siswa untuk berpikir tingkat tinggi. Salah satu mata kuliah yang menuntut pemikiran tingkat tinggi adalah analisis riil. Dalam mata kuliah ini, ada pembuktian matematika yang sering menjadi kesulitan mahasiswa, sehingga terdapat banyak kesalahan dalam prosesnya. Tujuan dari penelitian ini adalah untuk mengidentifikasi kesalahan mahasiswa dalam membuktikan pada materi kekonvergenan. Mahasiswa diklasifikasikan ke dalam kemampuan tinggi, kemampuan sedang, dan kemampuan rendah. Satu mahasiswa dari setiap kemampuan diambil secara acak dan diwawancarai untuk mendapatkan data tentang kesalahan mahasiswa. Subjek penelitian dari penelitian tersebut adalah 3 orang mahasiswa Jurusan Matematika Universitas Sebelas Maret Surakarta. Jenis kesalahan mahasiswa didasarkan pada prosedur analisis kesalahan newman adalah kesalahan membaca, memahami, transformasi, keterampilan proses, dan kesalahan pengkodean. Hasil dari penelitian tersebut adalah: (1) siswa berkemampuan tinggi membuat kesalahan dalam keterampilan proses; (2) siswa berkemampuan sedang memiliki kesalahan dalam transformasi dan keterampilan proses; dan (3) siswa berkemampuan rendah membuat kesalahan dalam transformasi, proses, dan pengkodean. Penelitian pada tulisan ini juga bertujuan untuk menganalisis kesalahan mahasiswa dengan menggunakan indikator Newman pada mata kuliah logika dan himpunan.

\section{METODE PENELITIAN}

Metode penelitian yang digunakan pada penelitian ini adalah penelitian studi kasus. 69 orang mahasiswa yang mengambil mata kuliah logika dan himpunan diberikan soal pemecahan masalah yang terkait dengan topik pembuktian matematis. Soal yang diberikan telah divalidasi oleh teman sejawat. Bentuk soal yang diberikan dapat dilihat pada Tabel 2.

Tabel 2. Soal topik pembuktian matematis

\begin{tabular}{cl}
\hline No & \\
\hline 1 & Tentukanlah negasi dari $p \rightarrow(-q \vee r)$. \\
2 & $\begin{array}{l}\text { Ubahlah bentuk pernyataan }(p \leftrightarrow q) \rightarrow(s \leftrightarrow r) \text { sehingga diperoleh bentuk-bentuk pernyataan ekivalen yang hanya } \\
\text { menggunakan penghubung negasi, konjungsi, dan disjungsi. }\end{array}$ \\
\hline
\end{tabular}

Lembar jawaban mahasiswa dianalisis dengan menggunakan prosedur NEA (Newman's Error Analisis). Mahasiswa juga diwawancarai dengan pertanyaan terbuka mengenai jawaban yang diberikan.

\section{HASIL DAN PEMBAHASAN}

Hasil dari penelitian ini dapat dilihat pada Tabel 3, pada tabel tersebut menunjukkan bagaimana kesalahan mahasiswa dalam menjawab pertanyaan nomor 1.

Tabel 3. Deskripsi jawaban mahasiswa untuk soal nomor 1

\begin{tabular}{clc}
$\begin{array}{c}\text { Langkah } \\
\text { NEA }\end{array}$ & \multicolumn{1}{c}{ Deskripsi jawaban mahasiswa } & $\begin{array}{c}\text { Jumlah } \\
\text { mahasiswa }\end{array}$ \\
\hline \multirow{2}{*}{ Membaca } & $\begin{array}{l}\text { Mahasiswa dapat membaca instruksi masalah dengan baik, ketika } \\
\text { diwawancarai mahasiswa dapat memaknai masalah yaitu menentukan } \\
\text { negasi dari proposisi yang diberikan }\end{array}$ & 69 orang \\
\hline
\end{tabular}


Lanjutan Tabel 3.

Tabel 3. Deskripsi jawaban mahasiswa untuk soal nomor 1

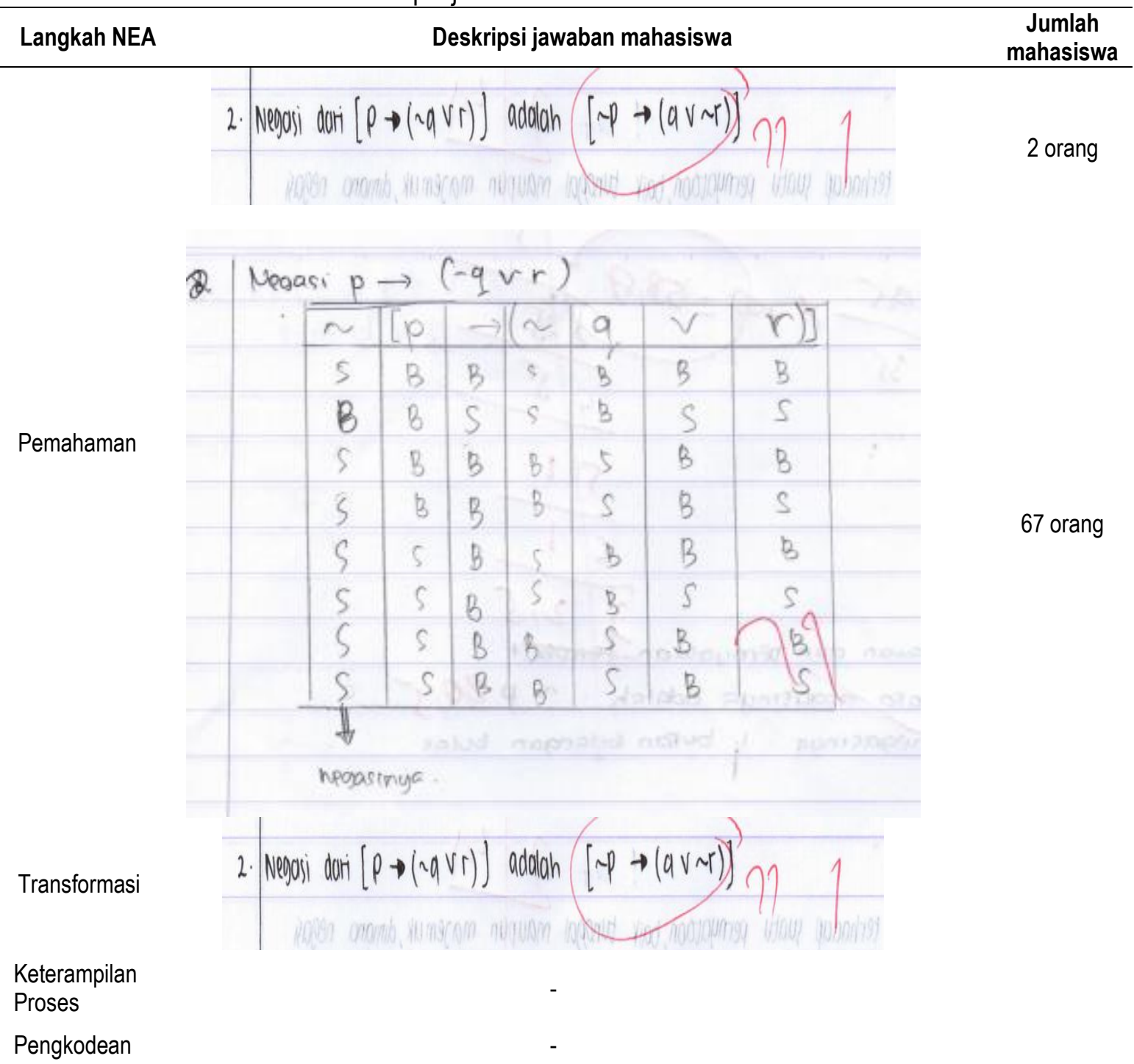

Uraian pada Tabel 3 merupakan hasil tabulasi dari jawaban mahasiswa. Berdasarkan uraian dari tabel tersebut bahwa seluruh mahasiswa dapat membaca permasalahan dengan jelas yaitu menentukan negasi dari proposi dari masalah yang diberikan. Selanjutnya jawaban siswa di tabulasi, dua orang mahasiswa paham dengan masalah yaitu menentukan negasi dari proposisi, namun salah dalam mentransformasikan, memproses dan mengkode karena tidak memahami proses penggantian lambang "jika maka". Jika ditransformasi kedalam bentuk negasi akan berubah kedalam bentuk negasi pernyataan pertama dikonjungsikan dengan pernyataan kedua. Sebanyak 67 mahasiswa tidak memahami maksud dari soal. Mahasiswa malah menentukan nilai kebenaran dari proposisi yang diberikan. Proses tersebut hanya berhenti pada fase transformasi, sedangkan kesalahan pada keterampilan proses dan pengkodean mahasiswa tidak dapat dilihat karena mahasiswa tidak dapat memahami masalah dengan benar.

Selanjutnya disajikan hasil wawancara penulis dengan mahasiswa yang melakukan penyelesaian masalah dengan menentukan tabel kebenaran.

Pewawancara : Apakah paham dengan maksud soal?

Mahasiswa : Paham, menentukan negasi dari proposisi.

Pewawancara : Kenapa menentukan nilai kebenaran dari proposisi?

Mahasiswa : Yang terbayang langsung menentukan nilai kebenarannya Bu?

Pewawancara : Baik lah. 
Berdasarkan hasil wawancara diketahui bahwa mahasiswa paham apa itu negasi, namun mahasiswa langsung tertuju atau mengambil keputusan untuk menentukan nilai kebenaran, bukan mentransformasikan kepada negasi dari sebuah proposisi.

Selanjutnya akan disajikan jawaban mahasiswa untuk masalah kedua pada Tabel 4.

Tabel 4. Deskripsi jawaban mahasiswa untuk soal nomor 2

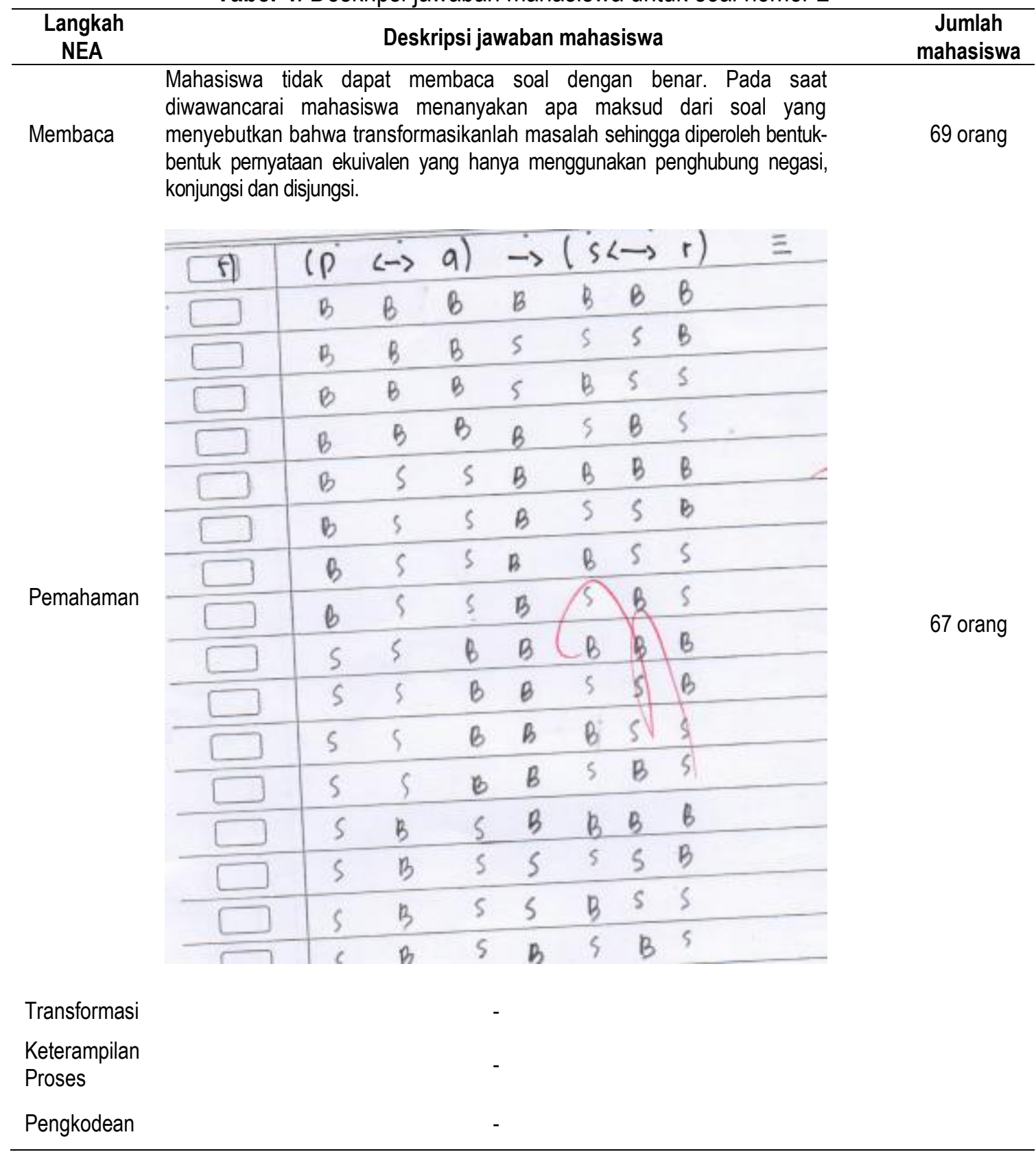

Berdasarkan Tabel 4 diperoleh hasil bahwa seluruh mahasiswa tidak mampu membaca maksud soal. Mahasiswa tidak dapat memaknai bahwa soal yang dimaksudkan adalah mengubah simbol pada proposisi sehingga menghasilkan proposisi baru yang hanya menggunakan simbol "atau" serta "dan". Akibat dari hal tersebut seluruh mahasiswa melakukan kesalahan yang sama yaitu dengan menentukan nilai kebenaran dari proposisi dan tidak menjawab maksud dari masalah.

Banyak hal yang melatarbelakangi kelemahan mahasiswa dalam melakukan kesalahan pada materi logika. Faktor eksternal utama yang mempengaruhi hal tersebut adalah bagaimana pendidik mengajar dalam proses pembelajaran (Harisman et al., 2019a). Faktor pendidik dapat berupa bagaimana pendidik bersikap atau attitude dan beliefs pendidik dalam pembelajaran seperti meyakini mahasiswa adalah manusia yang memiliki pengetahuan sehingga ilmu itu seharusnya 
dikonstruksi dan bukan ditransfer (Harisman et al., 2019b, 2019c). Selanjutnya bagaimana pendidik merefleksi proses pembelajaran yang telah dilakukan juga memberikan pengaruh terhadap pemahaman mahasiswa (Harisman et al., 2018). Pendidik yang selalu merefleksi proses pembelajaran akan selalu memperbaiki proses yang kurang tepat dalam pembelajaran. Pendidik juga harus mampu mengidentifikasi kesulitan-kesulitan mahasiswa dengan mengamati learning obstacle mahasiswa (Maarif et al., 2019; Fauzan et al., 2019). Namun, terkadang kesulitan mahasiswa tidak dapat diungkapkan melalui lisan, maka pendidik juga harus dapat mengidentifikasi hal tersebut dari sumber lain, seperti gesture mahasiswa atau gerak-gerik mahasiswa. Banyak penelitian ahli yang sudah melakukan identifikasi terhadap kesulitan belajar peserta didik melalui gesture diantaranya penelitian yang dilakukan Harun et al. (2019); Noto et al. (2017).

Selain faktor pendidik, faktor bahan ajar juga merupakan faktor eksternal lain yang mempengaruhi mahasiswa dalam proses pembelajaran. Pendidik harus mampu mengembangkan bahan ajar yang sesuai dengan kemampuan mahasiswa (Kariman et al., 2019).

\section{KESIMPULAN}

Mahasiswa cenderung melakukan kesalahan pada saat membaca dan memahami masalah pada materi logika dan himpunan terutama pada materi logika. Kesalahan siswa pada fase transformasi. keterampilan proses, pengkodean tidak dapat diidentifikasi karena mahasiswa cenderung melakukan kesalahan pada tahapan awal yaitu membaca dan memahami masalah.

\section{REKOMENDASI}

Rekomendasi dari penelitian ini adalah mengkaji secara spesifik penyebab dari kesalahan mahasiswa dalam materi logika, dan menemukan solusi yang dapat mengatasi penyebab tersebut.

\section{UCAPAN TERIMAKASIH}

Terima kasih kepada mahasiswa angkatan 2019 Pendidikan Matematika Universitas Negeri Padang yang telah mengikuti perkuliahan dan dapat bekerja sama dengan baik dalam wawancara maupun menjawab masalah yang diberikan.

\section{DAFTAR PUSTAKA}

Fauzan, A., Harisman, Y., \& Arini. (2019). Analysis of students' strategies in solving multiplication problems. International Journal of Scientific and Technology Research, 8(10), 568-573.

Harisman, Y., Kusumah, Y. S., \& Kusnandi, K. (2018). Teachers' reflections on students' mathematical problem solving in junior high school. Journal of Physics: Conference Series, 1088. https://doi.org/10.1088/1742-6596/1088/1/012011.

Harisman, Y., Kusumah, Y. S., \& Kusnandi, K. (2019a). How teacher professionalism influences student behaviour in mathematical problem-solving process. Journal of Physics: Conference Series, 1188(1). https://doi.org/10.1088/1742-6596/1188/1/012080.

Harisman, Y., Kusumah, Y. S., \& Kusnandi, K. (2019b). Beliefs of junior high school teachers on learning process on mathematical problem solving. Journal of Physics: Conference Series, 1157(3). https://doi.org/10.1088/1742-6596/1157/3/032112.

Harisman, Y., Kusumah, Y. S., \& Kusnandi, K. (2019c). The attitude of senior high school teachers on mathematical problem solving. Journal of Physics: Conference Series, 1318(1). https://doi.org/10.1088/1742-6596/1318/1/012087. 
Harun, L., Darhim, D., Dahlan, J. A., Harisman, Y., Sovia, A., \& Bakar, M. T. (2019). Students' gesture of naive, routine, and shopisticated behavior oriented on mathematical problem solving. Journal of Physics: Conference Series, 1157(4). https://doi.org/10.1088/1742$6596 / 1157 / 4 / 042074$.

Kariman, D., Harisman, Y., Sovia, A., \& Prahmana, R. C. I. (2019). Effectiveness of guided discovery-based module: A case study in Padang city, Indonesia. Journal on Mathematics Education, 10(2), 239-250.

Kristianto, E., Mardiyana, \& Saputro, D. R. S. (2019). Analysis of students' error in proving convergent sequence using newman error analysis procedure. Journal of Physics: Conference Series, 1180(1). https://doi.org/10.1088/1742-6596/1180/1/012001.

Maarif, S., Perbowo, K. S., Noto, M. S., \& Harisman, Y. (2019). Obstacles in constructing geometrical proofs of mathematics-teacher-students based on boero's proving model obstacles in constructing geometrical proofs of mathematics-teacher-students based on boero's proving model. Journal of Physics: Conference Series, 1315012043. https://doi.org/10.1088/1742-6596/1315/1/01204.

Newman, M. A. (1983). Strategies for diagnosis and remediation. Sydney: Harcourt, Brace Jovanovich.

Noto, M. S., Harisman, Y., Harun, L., Amam, A., \& Maarif, S. (2017). Adult gesture in collaborative mathematics reasoning in different ages. Journal of Physics: Conference Series, 895(1). https://doi.org/10.1088/1742-6596/895/1/012048.

Son, A. L., Darhim, \& Fatimah, S. (2019). An analysis to student error of algebraic problem solving based on Polya and Newman theory. Journal of Physics: Conference Series, 1315(1). https://doi.org/10.1088/1742-6596/1315/1/012069.

Sumule, U., Amin, S. M., \& Fuad, Y. (2018). Error analysis of indonesian junior high school student in solving space and shape content pisa problem using newman procedure. Journal of Physics: Conference Series, 947(1). https://doi.org/10.1088/1742-6596/947/1/012053.

Triliana, T., \& Asih, E. C. M. (2019). Analysis of students' errors in solving probability based on newman's error analysis. Journal of Physics: Conference Series, 1211(1). https://doi.org/10.1088/1742$6596 / 1211 / 1 / 012061$. 